\title{
SOCIOECONOMIC IMPACT OF MOTORCYCLE ACCIDENT VICTIMS IN THE EMERGENCY ROOM OF A HOSPITAL (PART 2)
}

\author{
IMPACTO SOCIOECONÔMICO EM VÍTIMAS DE ACIDENTE \\ DE MOTO NA EMERGÊNCIA DE UM HOSPITAL (PARTE 2)
}

\author{
Cintia Kelly Bittar ${ }^{1}$ (D), Alberto Cliquet Júnior ${ }^{2}$ (i), Vinícius Samuel Dias Alves da Costa ${ }^{1}$ (1), \\ ana Carolina de Freitas PaCheCO ${ }^{1}$ (i), Renato Lazarin Ricci ${ }^{1}$ (i) \\ 1. Pontifícia Universidade Católica de Campinas, School of Medical Sciences, Campinas, SP, Brazil. \\ 2. Universidade Estadual de Campinas, School of Medical Sciences, Department of Orthopedics and Traumatology, Campinas, SP, Brazil.
}

\section{ABSTRACT}

Objective: To evaluate the socioeconomic impact of motorcycle accidents of a metropolis with one million inhabitants treated by a university hospital in 2017. To study hospital cost and time of victims, evaluate definite and incapacitating sequelae, and analyze patient's insertion in the labor market six months after the accident. Methods: Retrospective study of 62 victims of motorcycle accidents treated in the emergency room and referred for surgical procedure in a university hospital. Data were collected from medical records and answers via telephone six months after the trauma. Results: Injuries related to motorcycle accident resulted in high hospital costs. Average loss per patient was $R \$ 17,555$. Of those who answered the functional impact questionnaire, $64 \%$ were on paid leave by INSS and $84 \%$ presented partial or permanent physical disabilities after the accident. Only 9 people (36\%) received any kind of financial benefit from public authorities. Conclusion: High costs are directly related to hospitalization time and surgical needs. Most victims needed financial help and had their social lives aggravated. Investments in motorcyclists' awareness of traffic laws and use of safety equipment are needed, as well as in road infrastructure. Level of evidence II, Prognostic studies.

Keywords: Accidents, Traffic. Socioeconomic Factors. Wounds and Injuries.

\section{RESUMO}

Objetivo: Avaliar o impacto socioeconômico de acidentes motociclísticos de uma metrópole com mais de um milhão de habitantes atendidos, no ano de 2017, em um hospital universitário. Estudar custo e tempo de internação hospitalar das vítimas, avaliar sequelas definitivas e incapacitantes e analisar a inserção no mercado de trabalho seis meses depois do acidente. Métodos: Estudo retrospectivo de 62 pacientes vítimas de acidentes motociclísticos, atendidos na urgência e emergência, levados para procedimento cirúrgico de um hospital universitário. Coleta de dados através do levantamento de prontuários e contato telefônico seis meses após o trauma. Resultados: Lesões relacionadas às vítimas implicaram elevados custos hospitalares. Prejuízo médio por paciente foi de $R \$ 17.555$. Dos que responderam ao questionário do impacto funcional, 64\% ficaram afastados da atividade laboral pelo INSS e 84\% apresentaram incapacidades físicas parciais ou permanentes após o acidente. Apenas 9 (36\%) receberam algum tipo de benefício financeiro do governo. Conclusão: Elevados custos estão diretamente relacionados ao tempo de internação e necessidades cirúrgicas. A maioria das vítimas necessitou de auxílio financeiro e teve sua vida social prejudicada. Investimentos em conscientização dos motociclistas, para que conduzissem respeitando as leis de trânsito e utilizando equipamentos de segurança, e na infraestrutura das rodovias são necessários. Nível de evidência II, Estudo prognóstico.

Descritores: Acidentes de Trânsito. Fatores Socioeconômicos. Ferimentos e lesões.

Citation: Bittar CK, Cliquet A Jr, Costa VSDA, Pacheco ACF, Ricci RL. Socioeconomic impact of motorcycle accident victims in the emergency room of a hospital (Part 2). Acta Ortop Bras. [online]. 2020;28(3):149-51. Available from URL: http://www.scielo.br/aob.

\section{INTRODUCTION}

The increase in the number of motorcycles circulating over the years is a consequence of the low cost, ease of locomotion and fuel efficiency of this vehicle. However, this increase has grown proportionally to the number of traffic accidents, making them a major problem for public health worldwide, since they have been considered one of the main causes of morbidity and mortality in the world, according to Martins et al. ${ }^{1}$ and Sant'Anna et al. ${ }^{2}$
Martins et al. ${ }^{1}$ also mention that the highest rates of traffic accidents occur in low- or medium-development countries, of which Brazil is considered part, according to the World Health Organization (WHO). In Brazil, mortality grew seven times between 1998 and 2008, as well as the number of hospitalizations, which grew by $83 \%$ in 2000. Also, the growth of the motorcycle fleet is supported by government policies, given the manufacturing stimulation, the possibility of financing the product and its cost reduction.

All authors declare no potential conflict of interest related to this article.

The study was conducted at Pontifícia Universidade Católica de Campinas, Center for Life Sciences, Medical School, Campus II.

Correspondence: Vinícius Samuel Dias Alves da Costa. Av. John Boyd Dunlop, Campinas, SP, Brazil, 13060904. viniciusssamuel@gmail.com 
Owning a motorcycle has some advantages, such as avoiding congested roads, low buying and maintenance cost, and fuel economy, in addition to its increasing use in the labor market (motorcycle taxi and deliveries) when compared with other means of transportation. Therefore, the motorcycle use in Brazil is increasing significantly.1,3 This is evidenced in the study by Sant'Anna et al. ${ }^{2}$ Thus, the need for new public policies to improve public health by reducing the number of accidents is evident.

Our study evaluated the socioeconomic impact of motorcycle accidents that occurred in a metropolis with more than one million inhabitants, in 2017, on the lives of victims treated in a reference university hospital, their definitive and disabling sequelae, their reintegration into the labor market after six months of the event and, finally, the time of hospital stay and its costs.

\section{OBJECTIVE}

To evaluate the socioeconomic impact of motorcycle accidents that occurred in a metropolis with more than one million inhabitants, in 2017 , on the lives of victims attended in a reference university hospital, through medical records and questionnaires answered via telephone with patients addressing their definitive and disabling sequelae and their reintegration into the labor market after six months of the accident. Moreover, to analyze the influence of cost and hospitalization time for socioeconomic impact.

\section{METHODS}

This is a retrospective cross-sectional study conducted at the PUC-Campinas University Hospital, filed by the Research Ethics Committee with registration on Plataforma Brasil under the number 88812818.3.0000.5481, in which the medical record analysis of 62 victims of motorcycle accident was performed in Campinas, São Paulo, Brazil, in 2017 (from January to December). The patients were treated primarily in the emergency room of a university hospital of reference and required a surgical procedure.

Data such as sex, age group, cost and hospital stay were evaluated in 62 medical records. However, of this total, only 25 patients answered the phone call after six months of the accident, providing information regarding their expenses after hospital discharge, removal and acquisition of benefit by the National Institute of Social Security (INSS), receipt compulsory insurance that covers personal damages caused by road vehicles (DPVAT), return to motorcycle activities and comparison of physical integrity before the accident and after six months of recovery.

Data regarding patients' hospitalization costs were obtained from the Billing sector of the PUC-Campinas Hospital. The remaining data (age group, sex and location of injuries) were obtained from medical records recorded in the Orthopedics and Traumatology service of the same hospital, and answers were obtained from a questionnaire via telephone, with the interviewee's consent.

\section{RESULTS}

The age of the 62 victims involved in motorcycle accidents ranges between 14 and 62 years (mean age of 31 years), in which $11.3 \%(7)$ ranged between 14 and 18 years, 43.6\% (27) between 19 and 30 years, and $45.1 \%$ (28) over 30 years. Out of 62 patients, $77.4 \%$ (48) were male and $22.6 \%$ (14) female. All patients were from Campinas. In the evaluation of medical records, we observed the high hospital costs were, on average, $R \$ 27,781$ per patient (ranging from $R \$ 3,101$ to $R \$ 225,500$ ), and $95 \%$ of them (59) caused an average loss of $R \$ 17,555$ and $5 \%$ (3) caused an average profit of $R \$ 203,396$, which are directly proportional throughout the hospitalization period, whose mean time was 13 days (1-87 days), as well as the extent and complexity of fractures. Patients who gave financial losses
(95\%) to the hospital correspond to those treated in the Brazilian Unified Health System (SUS), while those who gave profit were covered by health insurance (5\% - 1.6\% each), such as Bradesco, Amil and Unimed.

During data analysis, we observed that all were subjected to surgical procedure and that patella lesions had the lowest cost, followed by polyfractured patients with lesions associated with lower limbs (tibia, fibula and femur) and upper limbs (radio and humerus). Traumatic brain injury corresponds to $3 \%$ of cases and brachial plexus injury to $1.6 \%$. However, what most contributed to the increased cost were open-book fractures (4.8\% of cases) in the case of polytraumatic and polyfractured patients, with other structures such as urethra, ureters and bladder affected or with abdominal trauma. Of the $4.8 \%$ of patients who suffered open-book fractures, $1.6 \%$ was covered by Bradesco's Health Plan, avoiding major losses to the university hospital, since the amount spent would be $R \$ 225,550$.

Regarding the 25 patients who responded via telephone, 21 (84\%) were male and 4 (16\%) were female, aged between 17 and 62 years (mean of 28.3 years) and $68 \%$ were aged between 15 and 35 years. The average time of stay was 9 days (1-20 days), with hospital costs, on average, of $\mathrm{R} \$ 16,307$ per patient, all of which caused financial loss to the hospital, on average, of $R \$ 10,814$ per patient. All patients analyzed had hospitalizations covered by SUS. Regarding the functional evaluation and socioeconomic impact of the 25 patients after six months of the motorcycle accident, we observed that 16 patients (64\%) were on paid leave (INSS), and 8 (50\%) were still absent, 6 (24\%) presented polyfractures and most lesions (37\%) were solely in the left lower limb. Only 9 patients (36\%) received some kind of benefit (sickness aid, accident aid, disability retirement, etc.), 11 (44\%) used DPVAT insurance and 15 (60\%) needed extra financial resources after the accident.

Of the means of transport used for treatment, $16 \%$ were buses, $40 \%$ owned or borrowed car, $24 \%$ ambulance of the municipality, $8 \%$ UBER, and $12 \%$ did not undergo treatment. Most victims, 21 (84\%), underwent follow-up with physical therapists and only 1 (4\%) water aerobics after the accident. Regarding the practice of physical activities six months after the accident, 21 patients (84\%) presented partial physical disabilities and only 4 patients (16\%) did not present transient physical disabilities. In the recovery period after the accident, 20 (80\%) patients were helped by the mother and/or father, 3 (12\%) by the wife and 2 (8\%) by a brother.

Only $4(16 \%)$ patients showed interest in returning to their activities with the motorcycle after the accident.

\section{DISCUSSION}

In 2005, the cost of hospitalizations resulting from motorcycle accidents in Brazil reached $R \$ 31$ million. About $R \$ 10$ million of this amount were in the state of São Paulo. It is noteworthy that the costs of SUS with hospitalizations resulting from motorcycle accidents totaled $R \$ 58$ million from 2001 to 2005 only in the Southeast region. The analysis of hospitalizations of 62 patients in a reference hospital in Campinas found that the high costs of hospital admissions were caused by motorcycle accidents in 2017. All victims underwent surgery, contributing to high hospital expenses, and all hospitalizations were made by SUS.

A similar study conducted by Diniz, ${ }^{3}$ in the city of Goiânia, with 122 medical records, reported that the hospital costs of the city's reference hospital were, on average, $\mathrm{R} \$ 20,000$ per patient. A difference of $R \$ 7,781$ was observed when compared with the expenses of the reference hospital of Campinas. This is justified by the fact that the hospitalization period in Campinas were greater than those in Goiânia (longer period of 25 days). Considering that hospital time is directly proportional to the cost, the expenses of the hospital in Campinas were therefore naturally higher. Moreover, all the victims 
assisted in the metropolitan city underwent surgery, and some had several structures simultaneously affected, such as urethra, ureters, bladder, pulmonary contusions and traumatic brain injury, increasing the complexity of trauma. On the other hand, in the city of Goiânia, only $80.3 \%$ (98) performed the same type of procedure, with the highest complication being a traumatic brain injury (10.6\% of the cases). Studies by Ankarath et al. ${ }^{4}$, Zargar et al. ${ }^{5}$ and Nwadiaro et al. ${ }^{6}$ confirm that traumatic brain and abdominal traumas are responsible for reducing survival rates in these types of accidents. All of these facts also contribute to increased hospital spending. Regarding functional impact, the study conducted in Goiânia and the study of Chichom-Mefire et al. ${ }^{7}$ showed that limb injuries provide a longer recovery period for the victim and, consequently, a major impact on their social life. Our study had similar results, since most victims (84\%) could not perform the same physical activities after six months of trauma, $16 \%$ were on paid leave by INSS and $60 \%$ needed extra financial resources during the treatment period after the accident. Moreover, the time of absence of these patients associated with functional deficit after the accident were responsible for the inability of these patients to return to their work routine, remaining, in many cases, unemployed for a long period.

According to the Brazilian Ministry of Health, ${ }^{8}$ to reduce the number of victims, traffic accidents must be treated as a health promotion issue with the development of intersectoral projects to stimulate the participation of the entire population and the adoption of more supportive behaviors, which aim both at traffic education and information on the physical consequences of motorcycle accidents. All this correlates with the purpose of our study, which is to promote preventive guidelines for the epidemiological group most vulnerable to traffic accidents. For such, it is essential to raise society's awareness of traffic laws and, at the same time, use of safety equipment to reduce the extent of fractures and, consequently, hospital time and financial expenses, as already reported by Phillip et al. ${ }^{9}$, from de Rome et al. ${ }^{10}$, Heldt et al..$^{11}$ and Kim et al. ${ }^{12}$ In addition, improving the infrastructure of streets and roads is indispensable for a safer and more adequate circulation of motor vehicles.

\section{CONCLUSION}

The extent and complexity of fractures and other injuries, associated with prolonged hospitalization time significantly influence the hospital costs of victims of motorcycle accidents, generating a great socioeconomic imbalance in SUS and in health plans, and in victims' expenses with care after hospital discharge. Thus, our study provides preventive guidelines for the epidemiological group most vulnerable to traffic accidents and society awareness traffic laws and, at the same time, use of safety equipment such as helmets and appropriate clothing, which contribute to reducing the extent of fractures, hospital time and financial expenses that victims may have with institutional care, according to Phillip et al. ${ }^{9}$, de Rome et al. ${ }^{10}$, Heldt et al. ${ }^{11}$, and Kim et al. ${ }^{12}$.

AUTHORS' CONTRIBUTIONS: Each author contributed individually and significantly to the development of this article: CKB: design, review and approval of the final version of the article; ACJ: design, review and approval of the final version of the article. VSDAC: data collection, analysis and interpretation, and writing; ACFP: data collection, analysis and interpretation; RLR: data collection, analysis and interpretation.

\section{REFERENCES}

1. Martins ET, Boing AF, Peres MA. Mortalidade por acidentes de motocicleta no Brasil: análise de tendência temporal. Rev Saude Publica [Internet]. 2013 [cited 2017 Oct 27];47(5):931-41. Available from: http://bit.ly/2RawnMU

2. Sant'Anna FL, Andrade SM de, Sant'Anna FHM, Liberatti CLB. Acidentes com motociclistas: comparação entre os anos 1998 e 2010. Rev Saude Publica [Internet]. 2013 [cited 2017 Oct 27];47(3):607-15. Available from: http://bit.ly/2tX5156

3. Diniz A. Internação hospitalar por acidente de moto [monografia]. Brasília, DF: Universidade Católica de Brasília; 2012.

4. Ankarath S, Giannoudis PV, Barlow I, Bellamy MC, Matthews SJ, Smith RM. Injury patterns associated with mortality following motorcycle crashes. Dep Trauma Orthopaedic. 2002 Jul;33(6):473-477.

5. Zargar M, Khaji A, Karbakhsh M. Pattern of motorcycle-related injuries in Tehran, 1999 to 2000L a study in 6 hospitals. East Mediterr Health J. 2006 Jan-Mar;12(1-2):81-7.

6. Nwadiaro HC, Ekwe KK, Akpayak IC, Shitta H. Motorcycle injuries in north-central Nigeria. Niger J Clin Pract. 2011 Aug;14(2):186-9.

7. Chichom-Mefire A, Atashili J, Tsiagadigui JG, Fon-Awah C, Ngowe-Ngowe M. A prospective pilot cohort analysis of crash characteristics and pattern of injuries in riders and pillion passengers involved in motorcycle crashes in an urban area in Cameroon: lessons for prevention. BMC Public Health. 2015 Sep;15:915.

8. Brasil. Ministério da Saúde. Secretaria de Políticas de Saúde. Coordenação do Projeto de Promoção da Saúde. Projeto de redução da morbimortalidade por acidente de trânsito: mobilizando a sociedade e promovendo a saúde. Brasília, DF; 2002.

9. Philip AF, Fangman W, Liao J, Lilienthal M, Choi K. Helmets prevent motorcycle in juries with significant economic benefits. Traffic Inj Prev. 2013 May; 14(5):496-500.

10. de Rome L, Ivers R, Fitzharris M, Haworth N, Heritier S, Richardson D. Effectiveness of motorcycle protective clothing: riders' health outcomes in the six months following a crash. Injury. 2012 Dec;43(12):2035-45.

11. Heldt KA, Renner CH, Boarini DJ, Swegle JR. Costs associated with helmet use in motorcycle crashes: the cost of not wearing a helmet. Traffic Inj Prev. 2012 Mar;13(2):144-9.

12. Kim CY, Wiznia DH, Averbukh L, Dai F, Leslie MP. The Economic Impact of Helmet Use on Motorcycle Accidents: A Systematic View and Meta-analysis of the Literature from the Past 20 Years. Traffic Inj Prev. 2015 Apr;16(7):732-8. 